\title{
Aplicability of respiratory muscle strength as part of the surgical risk scale based on Tonrrington and Henderson scoring system
}

\author{
Aplicabilidade da média das forças musculares \\ respiratórias como parte da escala de risco cirúrgico \\ baseada na escala de Torrington e Henderson
}

\section{Eliane Regina Ferreira Sernache de Freitas ${ }^{[a]}$, Aline Maria Tonin Leoni ${ }^{[b]}$}

[a] PhD in Sciences from the Federal University of São Paulo/Paulista Medical School (Unifesp/EPM), professor, University of Northern Paraná (Unopar), physiotherapist at Irmandade da Santa Casa de Londrina (Iscal), Londrina, PR - Brazil, e-mail: elianefe@sercomtel.com.br

[b] Specialist in Hospital Physiotherapy from the University of Northern Paraná (Unopar), physiotherapist at Hospital Zona Sul (HZS), Londrina, PR - Brazil, e-mail: alineleoni@hotmail.com

\begin{abstract}
Objective: Evaluate the applicability of mean percentage from the predicted value of respiratory muscle strength (maximal inspiratory pressure-MIP; maximal expiratory pressure-MEP), as (\% MIP + \% MEP)/2, as well as the peak expiratory flow (\% PEF) preoperatively, as part of a surgical risk scale for predicting the risk of postoperative pulmonary complications (PPC). Methods: Data on patients undergoing elective surgery of chest, abdomen and limbs were assessed preoperatively using the items and the scoring system proposed by the Torrington and Henderson, and replacing spirometry by the mean values of both ( $\%$ MIP + $\%$ MEP)/2 and \% PEF. Results: The proposed scale applied to 108 patients with a mean age of $55.2 \pm 14.0$ presented PPC rate of $37.0 \%$ ( $p=0.0001$ ), of which $20.0 \%$ were classified as high risk (HR), and $62.5 \%$ moderate risk (MR). The mean value of respiratory muscle strength showed a statistically significant correlation with PPC $(\mathrm{p}=0.000)$. Conclusion: The proposed scale allowed the appropriate stratification of patients at risk for development of PPC. The use of the mean values of ( $\%$ MIP + \% MEP)/2 and \% PEF based on the predicted values can be easily applied, making spirometry unnecessary.
\end{abstract}

Keywords: Postoperative complications. Respiratory muscle. Laparotomy. Thoracotomy. 


\section{Resumo}

Objetivo: Avaliar a aplicabilidade da média do percentual do valor predito das forças musculares respiratórias (pressão inspiratória máxima- $P I_{\max }$ pressão expiratória máxima- $P E_{\max }$ ), sendo \% $P I_{\max }+\% P E_{\max } / 2$, e do pico de fluxo expiratório (\% PFE) no pré-operatório, como parte de uma escala de risco cirúrgico para predizer o risco de complicação pulmonar pós-operatória (CPP). Métodos: Dados de pacientes submetidos à cirurgia eletiva de tórax, abdômen e membros foram analisados no pré-operatório utilizando os itens e a pontuação proposta pela escala de Torrington e Henderson, e substituindo a espirometria pela média do \% $P I_{\max }+\% P E_{\max } / 2$ e do \% PFE. Resultados: Na escala proposta aplicada a 108 pacientes com idade média de $55,2 \pm 14,0$ a taxa de CPP foi de 37,0\% ( $p=0,0001)$, onde 20,0\% foram classificados como de alto risco (RA) $e$ $62,5 \%$ risco moderado (RM). O percentual da média da força muscular respiratória apresentou uma correlação significante em relação à CPP na escala proposta $(p=0,000)$. Conclusão: $A$ escala proposta permitiu estratificar de maneira adequada pacientes com risco de CPP. A utilização da média do \% $P I_{\max }+\% P E_{\max } /$ 2 e do \% PFE, baseados nos valores preditos, podem ser facilmente aplicáveis, tornando-se desnecessária a realização da espirometria.

Palavras-chave: Complicações pós-operatórias. Músculos respiratórios. Laparotomia. Toracotomia.

\section{Introduction}

Postoperative pulmonary complications (PPC), especially in abdominal and thoracic surgeries, besides having high rates of morbidity and mortality, extend hospital stay and consequently increase costs to the health care (1).The prevention of PPCs has motivated numerous studies aimed at validating indices to predict surgical risks $(2,3)$.

The scoring system devised by Torrington and Henderson (4), which used spirometry associated with other risk factors of PPC was validated in 2000 (5). The conclusion was that the scale was able to estimate the probability of PPCs and mortality in three categories: high risk (HR), moderate risk (MR), and low risk (LR). However, spirometry, highly recognized in the 1970s and 80s (6), currently has been more advantageous for patients undergoing pulmonary resection (7) or presenting respiratory symptoms (8).

Some authors found that patients with decreased respiratory muscle strength (MIP and MEP) are at increased risk of developing PPC $(9,10)$.

Other authors have also suggested the inclusion of MEP in the risk scale proposed for patients undergoing cardiac surgery (11).

The present research suggests that considering the items evaluated as risk factors and the Torrington and Henderson scale, and replacing spirometry by both the predicted values MIP and MEP ( $\%$ MIP + \% $\mathrm{MEP}) / 2$, and the predicted peak expiratory flow (\%
PEF) in the preoperative period, the resulting scores can predict the risk of PPCs in patients undergoing elective surgery of the chest, abdomen and limbs.

\section{Methods}

After approval of the present project by the Research Ethics Committee of the Irmandade Santa Casa de Londrina, Parana State, Brazil (CEP 266/07), and after signed the consent form, a cross-sectional study was carried out, quantitative and observational, following the criteria established by the Strengthening the Reporting of Observational Studies in Epidemiology (Strobe) (12).

From October 2007 to February 2009, consecutive patients undergoing surgery with surgical incision in the chest, in abdominal or peripheral wall were evaluated at the Hospital Santa Casa de Londrina (HSCL), Londrina, Parana State, Brazil. Candidates who had some complications leading to emergency surgery, patients undergoing cardiac surgery, and laparoscopic surgery were excluded from the sample.

Of the 147 patients referred for preoperative evaluation, 39 (26.5\%) were not included in the study. Of these, 19 did not undergo the surgery proposed by changing the therapeutic approach, five refused to participate in the study, nine were discharged without performing surgery, four patients died in 
the preoperative stage, and two died during the surgical procedure.

All patients were evaluated by a single observer in the preoperative stage and monitored until hospital discharge or death. The evaluator did not provide patient data for physiotherapists and even for the surgical team. All individuals were attended as routine patients by physiotherapy service at HSCL.

Both the clinical history and physical examination were assessed by a standardized questionnaire, with the following settings: a) high or low thoracic and abdominal surgery referred to surgery with surgical incision in the chest, in abdominal wall, above or below the umbilicus, with intracavitary manipulation, while peripheral referred to the extremity surgery; b) smoker was defined as any individual who had smoked any type or quantity of tobacco for at least six months during the survey (13); c) respiratory symptomatic patient presenting acute or chronic cough and / or expetoration at the time of evaluation (2); d) lung disease referred to the evolution of chronic lung disease, symptomatic, with current treatment or not, and diagnosis previously established (14).

Respiratory muscle strength of the participants was assessed by measuring the maximal inspiratory pressure (MIP) and the maximal expiratory pressure (MEP), using an analog manometer (GERAR ${ }^{\circledR}$, with scale of -200 to $+200 \mathrm{~cm} \mathrm{H}_{2} \mathrm{O}$, capsule type sensor and spigot type connection). The examination for collecting data met the international standards established by the American Thoracic Society (2000) (15). To measure the MIP, the patient was asked to perform a forced inspiration from residual volume. For MEP, the subject was instructed to perform a maximal forced expiration from total lung capacity. All maneuvers were maintained for at least two seconds. The values obtained were compared to the table of normality for the Brazilian population (16), and expressed as percentage.

For PEF, a Peak Flow Meter (NCS) was used. The measurement was performed with the patient in sitting position, head erect, mouthpiece between the teeth and on the tongue. The patient was instructed to make a deep breath and then a forced expiration to analyze the expiratory flow $(\mathrm{l} / \mathrm{min})$. The highest value of three consecutive measurements was recorded as technically correct measured value, and additional measurements were performed when the two highest values of three maneuvers presented difference of more than $40 \mathrm{~L} / \mathrm{min}$. The values were compared with the predicted values of PEF for adults (17), and expressed as percentage (\%PEF).

At the end of the preoperative evaluation, each patient was classified in relation to the risk of developing PPC, according to the classification proposed by the Torrington and Henderson scale (HR - 0 to 3 points, MR - 4 to 6 points, LR - 7 to 11 points), but replacing the spirometry by the mean predicted value of MIP and MEP ( $\%$ MIP + MEP) $/ 2$ and the predicted PEF (\% PEF) (4) (Table 1).

In the postoperative period, daily monitoring of each patient was performed during the immediate postoperative period until hospital discharge or occurrence of death. The following definitions were considered as PPC: a) acute respiratory infection, patients who had radiological signs of pulmonary consolidation, body temperature $>38^{\circ} \mathrm{C}$, increased number of circulating leukocytes $>25 \%$ baseline number; tracheobronchitis was diagnosed with increasing amounts or purulent tracheobronchial secretion by normal chest radiography (18); b) atelectasis evidenced by chest radiography and with obvious clinical symptoms of acute respiratory symptom (2); c) acute respiratory failure, clinical picture resulting from the exchange pulmonary gas, acutely deficient requiring mechanical ventilation (2); d) endotracheal intubation or mechanical ventilation for more than 48 hours for treatment of acute respiratory failure, or need to aspiration of tracheobronchial secretion (2); e) bronchospasm characterized by wheezing on auscultation associated with acute respiratory symptoms and the necessity of drug therapy (2).

In patients who died, it was investigated by clinical, laboratory and medical inference data whether the causes were pulmonary origin. The causes of death of pulmonary origin were summarized into two major groups: 1) sepsis after pulmonary infection, when the inflammation was linked to a pulmonary infectious process in which hemodynamic instability emerged, unresponsive to volume replacement, dependence on vasoactive drugs, related to functional failure of at least two major organ systems(19); 2) acute respiratory failure.

Data were tested for normal distribution using the Kolmogorov-Smirnov test. Categorical variables were presented as absolute numbers and proportions, and the continuous variables as mean and standard deviation ( \pm SD). Student's $t$ test and Chisquare $\left(\mathrm{X}^{2}\right)$ were used to compare the presence or absence of PPC, and Spearman correlation was used 
Table 1 - Classification of the risk for PPC, based on the Torrington and Henderson scale (TH) with modifications, replacing spirometry by PEF and manovacuometry

\begin{tabular}{|c|c|}
\hline Risk Factors & Points \\
\hline Age over 65 years & 1 \\
\hline Overweight (BMI above 30) & 1 \\
\hline \multicolumn{2}{|l|}{ Surgical site: } \\
\hline thoracic & 2 \\
\hline abdominal & 2 \\
\hline other & 1 \\
\hline \multicolumn{2}{|l|}{ Pulmonary story: } \\
\hline current smoker & 1 \\
\hline cough and expectoration & 1 \\
\hline pulmonary disease & 1 \\
\hline \multicolumn{2}{|l|}{ Peak expiratory flow (PEF) and manovacuometry: } \\
\hline PEF $<50 \%$ predicted & 1 \\
\hline$\%$ mean predicted value ((MIP + MEP)/2): 65.0 to $74.9 \%$ & 1 \\
\hline$\%$ mean predicted value ((MIP + MEP)/2): 40.0 to $64.9 \%$ & 2 \\
\hline$\%$ mean predicted value ((MIP + MEP)/2): less than $40.0 \%$ & 3 \\
\hline \multicolumn{2}{|c|}{ Classification of risks for complications and mortality } \\
\hline Points & Risk \\
\hline $0-3$ & low \\
\hline $4-6$ & moderate \\
\hline $7-11$ & high \\
\hline
\end{tabular}

Note: PEF: peak expiratory flow; MIP: maximal inspiratory pressure; MEP: maximal expiratory pressure.

Source: Research data.

to correlate the PPC with the risk factors and the proposed scale (rs). Data were analyzed using the Statistical Package for Social Science (SPSS 17.0) at $\mathrm{p}<0.05$ significance level.

\section{Results}

One hundred and eight patients were studied, of whom 55 were male (50.9\%). The mean age was 56.2 \pm 14.0 years with an age range of $19-82$ years. Among the patients, 30 were aged $>65$ years $(27.8 \%)$, nine had a body mass index (BMI) $>30 \mathrm{~kg} / \mathrm{m}^{2}$ (8.3\%), 26 were smokers (24.1\%), 35 were symptomatic respiratory patients at the time of surgery (32.4\%), and 18 had chronic lung disease (16.7\%). Sixty-eight patients $(63 \%)$ underwent thoracic surgery. The mean predicted value for MIP in the preoperative period was $62.2 \pm 23.1$, while MEP and PEF were $71.5 \pm 25.8$, and
$61.3 \pm 24.5$, respectively. Regarding the risk of PPC, 43 patients $(39.8 \%)$ were classified as LR, 51 as MR, and 14 as HR (13\%) (Table 2).

Table 3 shows the relationship of the CPPs in patients according to the number of diagnoses. The most common event was the acute respiratory infection followed by tracheobronchitis occurring in 29 patients (29/108; $26.9 \%)$.

Although the CPPs was observed in 40 patients $(40 / 108 ; 37 \%)$, of the patients classified as HR $(14 / 108 ; 13.0 \%), 57.1 \%$ had CPPs $(p=0.000)$, and $71.4 \%$ died $(\mathrm{p}=0.001)$ (Table 4$)$.

There was a statistically significant correlation between the risk classification and PPC in the patients under study $(\mathrm{p}=0.000)$. However, Table 5 shows that only the parameters surgical site, chronic lung disease $(\mathrm{p}=0.020), \% \mathrm{PEF}<50 \%(\mathrm{p}=0.000)$, and $(\%$ MIP + \% MEP) $/ 2<75 \%(p=0.000)$ were significant in relation to PPC (Table 5). 
Table 2 - Characteristics of the patients $(n=108)$

\begin{tabular}{|c|c|c|}
\hline Characteristics & Results & $\mathrm{p}$ \\
\hline $\begin{array}{l}\text { Age (years) (mean } \pm S D \text { ) } \\
\quad \text { (Range) }\end{array}$ & $\begin{array}{c}56.2 \pm 14.0 \\
(19-82)\end{array}$ & 0.997 \\
\hline \multicolumn{3}{|l|}{ Age over 65 years $-n(\%)$} \\
\hline Yes & $30(27.8)$ & 0.000 \\
\hline No & 78 (72.2) & \\
\hline \multicolumn{3}{|l|}{ Gender - $\mathrm{n}(\%)$} \\
\hline male & $55(50.9)$ & 1.000 \\
\hline female & $53(49.1)$ & \\
\hline $\begin{array}{l}\mathrm{BMl}\left(\mathrm{Kg} / \mathrm{m}^{2}\right)-(\text { mean } \pm S D) \\
\text { (Range) }\end{array}$ & $\begin{array}{c}26.5 \pm 7.2 \\
(18-61)\end{array}$ & 0.081 \\
\hline \multicolumn{3}{|l|}{ BMl above $30 \mathrm{Kg} / \mathrm{m}^{2}$} \\
\hline Yes & $09(8.3)$ & 0.000 \\
\hline No & $99(91.7)$ & \\
\hline \multicolumn{3}{|l|}{ Current smoker - $n(\%)$} \\
\hline Yes & $26(24.1)$ & 0.000 \\
\hline No & $82(75.9)$ & \\
\hline \multicolumn{3}{|l|}{ Respiratory symptoms (preop) (cough / expectoration) - $n$ (\%) } \\
\hline Yes & $35(32.4)$ & 0.000 \\
\hline No & $73(67.6)$ & \\
\hline \multicolumn{3}{|l|}{ Previous lung disease (preop) $-n(\%)$} \\
\hline Yes & $18(16.7)$ & 0.000 \\
\hline No & $90(83.3)$ & \\
\hline \multicolumn{3}{|l|}{ Surgical site $-n(\%)$} \\
\hline thoracic & $68(63.0)$ & م000 \\
\hline upper abdominal & $20(18.5)$ & .000 \\
\hline other & 20 (18.5) & \\
\hline$\%$ of the predicted maximal inspiratory pressure (MIP) (preop) - (mean \pm SD) & $62.2 \pm 23.1$ & 0.000 \\
\hline$\%$ of the predicted maximal expiratory pressure (MEP) (preop) - (mean \pm SD) & $71.5 \pm 25.8$ & 0.000 \\
\hline$\%$ of the predicted peak expiratory flow (PEF) (preop) - (mean \pm SD) & $61.3 \pm 24.5$ & 0.000 \\
\hline \multicolumn{3}{|l|}{$\%$ of the predicted peak expiratory flow (PEF) (preop) $>50 \%$} \\
\hline Yes & $39(36.1)$ & $<0.001$ \\
\hline No & $69(63.9)$ & \\
\hline \multicolumn{3}{|l|}{ Risk of PPC } \\
\hline low & $43(39.8)$ & 0004 \\
\hline moderate & $51(47.2)$ & \\
\hline high & $14(13.0)$ & \\
\hline
\end{tabular}

Note: SD: standard deviation; DI: interquartile range; Preop: preoperative; PO: postoperative; PPC: postoperative pulmonary complications. Source: Research data. 
Table 3 - Distribution of PPCs observed while monitoring of patients

\begin{tabular}{lc}
\hline Type of PPC & Number of patients (\%) \\
\hline Acute respiratory infection and tracheobronchitis & $29(26.9)$ \\
Bronchospasm & $13(12.0)$ \\
Acute respiratory failure & $09(8.3)$ \\
Reintubation & $08(7.4)$ \\
Atelectasis & $04(3.7)$ \\
Prolonged mechanical ventilation (> 48 hours) & $04(3.7)$ \\
\hline
\end{tabular}

Source: Research data.

Table 4 - Distribution of patients $(n=108)$ with respect to the risk of PPC and the occurrence of death and hospital discharge

\begin{tabular}{|c|c|c|c|c|c|}
\hline & \multicolumn{3}{|c|}{$\begin{array}{c}\text { Risk of PPC } \\
\text { N (\%) }\end{array}$} & \multirow[b]{2}{*}{$\begin{array}{c}\text { Total } \\
\mathrm{N}=108 \\
(100.0)\end{array}$} & \multirow[b]{2}{*}{$p$} \\
\hline & $\begin{array}{c}\text { Low } \\
\text { (LR) } \\
N=43 \\
(39.8)\end{array}$ & $\begin{array}{c}\text { Moderate } \\
\text { (MR) } \\
\mathrm{N}=51 \\
(47.2)\end{array}$ & $\begin{array}{c}\text { High } \\
\text { (HR) } \\
\mathrm{N}=14 \\
(13.0)\end{array}$ & & \\
\hline \multicolumn{6}{|l|}{ PPC } \\
\hline Yes & $07(16.3)$ & $25(49.0)$ & 08 (57.1) & $40(37.0)$ & 0.000 \\
\hline No & $36(83.7)$ & $26(51.0)$ & $06(42.9)$ & $68(63.0)$ & \\
\hline \multicolumn{6}{|c|}{ Occurrence } \\
\hline High & $43(100.0)$ & 46 (90.2) & $10(71.4)$ & 99 (91.7) & 0.001 \\
\hline Death & $00(0.0)$ & $05(9.8)$ & 04 (28.6) & $09(8.3)$ & \\
\hline
\end{tabular}

Note: PPC: postoperative pulmonary complications.

Source: Research data.

Table 5 - Distribution of PPC with respect to the items evaluated on the scale proposed

(To be continued)

\begin{tabular}{|c|c|c|c|}
\hline \multirow[b]{2}{*}{ Variables } & \multicolumn{3}{|c|}{ Pulmonary complications } \\
\hline & Yes $(n=40)$ & No $(n=68)$ & $\mathrm{p}$ \\
\hline Age over 65 years & $13(32.5)$ & $17(25.0)$ & $0.405^{c}$ \\
\hline Overweight (BMI above 30) & $06(15.0)$ & $04(5.9)$ & $0.117^{c}$ \\
\hline \multicolumn{4}{|l|}{ Surgical site } \\
\hline Thoracic & $25(62.5)$ & 43 (63.2) & \\
\hline Upper abdominal & $12(30.0)$ & $08(11.8)$ & $0.000^{c}$ \\
\hline Peripheral & $03(7.5)$ & $17(25.0)$ & \\
\hline Current smoker & $06(15.0)$ & $20(29.40)$ & $0.092^{c}$ \\
\hline Cough / expectoration & $13(32.5)$ & $22(32.4)$ & $0.998^{c}$ \\
\hline Previous lung disease & $11(27.5)$ & $07(10.3)$ & $0.020^{\circ}$ \\
\hline PEF $<50 \%$ predicted & $23(57.5)$ & $16(23.5)$ & $0.000^{c}$ \\
\hline
\end{tabular}


Table 5 - Distribution of PPC with respect to the items evaluated on the scale proposed

(Conclusion)

\begin{tabular}{|c|c|c|c|}
\hline \multirow[b]{2}{*}{ Variables } & \multicolumn{3}{|c|}{ Pulmonary complications } \\
\hline & Yes $(n=40)$ & No $(n=68)$ & $\mathrm{p}$ \\
\hline \multicolumn{4}{|c|}{$\begin{array}{l}\text { Mean respiratory muscle strength } \\
(\% \text { MIP + \% MEP)/2 (\% predicted value) }\end{array}$} \\
\hline$>75 \%$ & 05 (12.5) & $41(60.3)$ & \multirow{4}{*}{$0.000^{\circ}$} \\
\hline 65 to 74.9 & $00(0.0)$ & $03(4.4)$ & \\
\hline 40 to 64.9 & $26(65.0)$ & $20(29.4)$ & \\
\hline$<39.9$ & 09 (22.5) & $04(5.9)$ & \\
\hline \multicolumn{4}{|l|}{ Risk of PPC } \\
\hline Low & $07(17.5)$ & $36(52.9)$ & \multirow{3}{*}{$0.001^{\circ}$} \\
\hline Moderate & $25(62.5)$ & 26 (38.2) & \\
\hline High & $08(20.0)$ & $06(8.8)$ & \\
\hline \multicolumn{4}{|l|}{ Occurrence } \\
\hline High & $31(77.5)$ & $68(100.0)$ & $0.000^{\circ}$ \\
\hline Death & $09(22.5)$ & $00(0.0)$ & \\
\hline
\end{tabular}

Note: c: Spearman correlation.

Source: Research data.

\section{Discussion}

Respiratory muscle dysfunction has been shown as an impact factor in the evolution of various clinical situations and surgical conditions $(10,20)$. Therefore, the main issue and goal of the present study was to evaluate whether the mean predicted value in respiratory muscle strength (\% MIP + \% MEP) $/ 2$ and the peak expiratory flow (\% PEF) could replace spirometry, stratifying the surgical risk in our population.

The incidence of PPC found in our sample was $37.0 \%$. This value is close to the mean found in other studies, whose values were around $30.0 \%(21,22)$. However, this difference may be due to the previous studies considered PPC only the situations leading to clinical manifestations such as pneumonia and acute respiratory failure, by increasing morbidity and postoperative mortality. However, it is known that any pulmonary complications should be considered important since often there is a connection between them, given that patients who develop acute respiratory failure initially present tracheobronchitis or atelectasis.

The overall mortality rate in our study was $8.3 \%$. This value is above that found in other studies $(23$, 24 ). This may be due to $63.0 \%$ patients underwent thoracic surgery, which increases the risk of morbidity and postoperative mortality (25). The cases of death were considered PPCs as they occurred due to pulmonary complications, which are in agreement with others authors $(2,10)$.

Age above 65 years was not significantly correlated with PPC. In agreement with this result, other authors (26) concluded that advanced age alone was not a risk factor for the increased PPC rate, once mortality and morbidity were more associated to the effects of aging on lung function, such as decreased lung elasticity, compliance and volumes, reduced arterial oxygen pressure $\left(\mathrm{PaO}_{2}\right)$, reduced upper airway reflexes, and patient's clinical condition than the chronological age.

In recent decades, obesity, defined as BMI $\geq 30$ $\mathrm{kg} / \mathrm{m}^{2}$ has grown in epidemic form in modern society. Obese individuals are susceptible to ineffective cough, atelectasis at the lung bases, and progressive hypoxemia, allowing installation of secretions and infections (27). In our study, obesity alone did not correlate with PPC, disagreeing with the results of previous studies. However, recently, the impact of obesity was assessed in a large cut to evaluate patients undergoing coronary intervention, and the findings showed that BMI $\geq 30 \mathrm{~kg} / \mathrm{m}^{2}$ did not influence the rate of adverse clinical events $(28,29)$. 
Patients with chronic respiratory disease and referring cough, phlegm and wheezing in the preoperative period have greater chance to develop PPC (4). In our study, despite no correlation was observed for cough and expectoration and PPC, chronic pulmonary disease had an important effect on the results. One explanation may be that, in data collection, data analysis overlapped when it was not possible to obtain information on the diagnosis of chronic lung disease, thus the diagnosis may have been replaced by the symptoms.

Smoking is a risk factor for the development of PPC, even those without lung disease (26). However, individual analysis found no significant correlation with PPC, probably due to $75.9 \%$ patients were nonsmokers.

Individual analysis of the predicted value of the maximal respiratory pressures (\% MIP + \% MEP)/ 2) stood out for the significant different correlation with PPC or death, which was also reported by other studies $(10,16)$. These authors also observed that the MIP alone allowed to associate the preoperative inspiratory dysfunction to CPP (10). However, this finding is controversial to the results found by other authors, who studied 117 patients aimed at developing a scale of PPC risk for coronary artery bypass surgery, and found MEP $\geq 75 \%$ of the predicted value, and inspiratory vital capacity $\geq 76 \%$ of the predicted value, which were considered as protective factors for the development of PPC (11). This may justify the aim of our study in drawing attention the mean values of both measurements to find the balance between $\%$ MIP and $\%$ MEP as the mean $\geq 75 \%$ a protective factor for PPC.

The PEF is a simple, fast and inexpensive methodology to assess lung function. Their values are influenced by age, sex, body weight and respiratory muscle strength, and have shown a positive correlation between vital capacity and forced expiratory volume in one second $\left(\mathrm{FEV}_{1}\right)$ (17). However, PEF does not allow differentiating between restrictive and obstructive ventilatory changes, but the decrease in $\mathrm{FEV}_{1}$ and PEF occurs in both changes, thus providing a good correlation between the measurements (30). In our study, the $\% \mathrm{PEF}<50 \%$ of the predicted value had a statistical correlation with PPC. This can justify the importance of the association of \% PEF based on the predicted value as a component of the risk scale of PPC.
The scores assigned to each of the variables for the proposed scale was based on the Torrington and Henderson scoring system (4), which were established empirically without statistical basis. In our study, the vast majority of patients (63\%) underwent thoracotomy. This fact may lead us to assume that the results reflect more what happens in thoracic procedures. However, considering the applicability of the scale, we observe that the type of surgical procedure and the presence of chronic lung disease contemplated three points, reaching the limit for LR. Added to the $32.4 \%$ patients with respiratory symptoms, as is common in this population, the scale gets one more point, placing it in the MR range, justifying the prevalence of the classification of our study. Some limitations were found in the present study, including the classification of diagnoses of primary diseases leading patients to the surgical procedure, especially the thoracotomy and upper abdominal surgery, once certain diseases such as cancer exposes the body to some degree of chronic inflammation with local and/ or systemic consequences. Another limitation was that the high and low abdominal surgeries have not been studied separately.

\section{Conclusion}

The proposed scale allowed to adequately stratify patients at risk of PPC. The use of both the mean values of respiratory muscle strength and PEF based on the predicted values can be globalized and easily applied, making spirometry unnecessary. These results may guide health professionals working with risk assessment for PPCs. In addition, they could allow standardization of procedures and comparison of results between services with the same profile.

\section{References}

1. Smetana GW. Postoperative pulmonary complications: an update on risk assessment and reduction. Cleve Clin J Med. 2009;76(Suppl 4):S60-5.

2. Pereira EDB, Faresim SM, Juliano Y, Fernandes ALG. Fatores de risco para complicações pulmonares no pós-operatório de cirurgia abdominal alta. J Pneumol. 1996;22:19-26. 
3. Pezzella AT, Adebonojo SA, Hooker SG, Mabogunje OA, Conlan AA. Complications of general thoracic surgery. Curr Probl Surg. 2000;37(11):733-858.

4. Torrington KG, Henderson CJ. Perioperative respiratory therapy (PORT). A program of preoperative risk assessment and individualized postoperative care. Chest 1988;93(5):946-51.

5. Faresin SM, Barros JA, Beppu OS, Peres CA, Atallah AN. Aplicabilidade da escala de Torrington e Henderson. Rev Assoc Med Bras. 2000;46(2):159-65.

6. Tisi GM. Preoperative evaluation of pulmonary function. Validity, indications, and benefits. Am Rev Respir Dis. 1979;119(2):293-310.

7. Bolliger CT. Evaluation of operability before lung resection. Curr Opin Pulm Med. 2003;9(4):321-6.

8. Faresin SM, Barros JA, Beppu OS, Peres CA, Atallah AN. Quem deve realizar a espirometria durante a avaliação pulmonar pré-operatória? Folha Med. 1998; 116(2):85-90.

9. Nomori H, Kobayashi R, Fuyuno G, Morinaga S, Yashima H. Preoperative respiratory muscle training. Assessment in thoracic surgery patients with special reference to postoperative pulmonary complications. Chest 1994;105(6):1782-8.

10. Bellinetti LM, Thomson JC. Respiratory muscle evaluation in elective thoracotomies and laparotomies of the upper abdomen. J Bras Pneumol. 2006;32(2):99-105.

11. Hulzebos EH, van Meeteren NL, De Bie RA, Dagnelie PC, Helders PJ. Prediction of postoperative pulmonary complications on the basis of preoperative risk factors in patients who had undergone coronary artery bypass graft surgery. Phys Ther. 2003;83(1):8-16.

12. Vandenbroucke JP, von Elm E, Altman DG, Gøtzsche PC, Mulrow CD, Pocock SJ, et al. Strengthening the Reporting of Observational Studies in Epidemiology (STROBE): explanation and elaboration. PLoS Med. 2007;4(10):e297.

13. World Health Organization. Guidelines for the conduct of the tobacco smoking surveys of the general population: report of a meeting. Geneva; 1992. (N/ WHO/SMO/83.4).
14. American Thoracic Society Statement. Standards for the diagnosis and care of patients with chronic obstructive pulmonary disease. Am J Respir Crit Care Med. 1995;152(5 Pt 2):77-120.

15. American Thoracic Society; European Respiratory Society. ATS/ERS Statement on respiratory muscle testing. Am J Respir Crit Care Med. 2002;166(4):518-624.

16. Neder JA, Andreoni S, Lerario MC, Nery LE. Reference values for lung function tests. II. Maximal respiratory pressures and voluntary ventilation. Braz J Med Biol Res. 1999;32(6):719-27.

17. Leiner GC, Abramowitz S, Small MJ, Stenby VB, Lewis WA. Expiratory peak flow rate. Standard values for normal subjects. Use as a clinical test of ventilatory function. Am Rev Respir Dis. 1963;88:644-51.

18. Murphy TF, Sethi S. Bacterial infection in chronic obstructive pulmonary disease. Am Rev Respir Dis. 1992;146(4):1067-83.

19. Bone RC. Immunologic dissonance: a continuing evolution in our understanding of the systemic inflammatory response syndrome (SIRS) and the multiple organ dysfunction syndrome (MODS). Ann Intern Med. 1996;125(8):680-7.

20. Laghi F, Tobin MJ. Disorders of the respiratory muscles. Am J Respir Crit Care Med. 2003;168(1):10-48.

21. Warner DO. Preventing postoperative pulmonary complications: the role of the anesthesiologist. Anesthesiology. 2000;92(5):1467-72.

22. Dimick JB, Chen SL, Taheri PA, Henderson WG, Khuri SF, Campbell DA Jr. Hospital costs associated with surgical complications: a report from the private-sector National Surgical Quality Improvement Program. J Am Coll.Surg. 2004;199(4):531-7.

23. Stanzani F, Oliveira MA, Forte V, Faresin SM. Torrington and Henderson and Epstein risk asessment scales: aplicability and effectiveness in lung resection. J Bras Pneumol. 2006;31(4):292-9.

24. Harpole DH Jr, DeCamp MM Jr, Daley J, Hur K, Oprian CA, Henderson WG, et al. Prognostic models of thirty-day mortality and morbidity after major pulmonary resection. J Thorac Cardiovasc Surg. 1999; 117(5):969-79. 
25. Saad IAB, Zambom L. Variáveis clínicas de risco préoperatório. Rev Ass Med Brasil. 2001;47(2):117-24.

26. Doyle RL. Assessing and modifying the risk of postoperative pulmonary complications. Chest. 1999;115(Suppl 5):S77-81.

27. Wilson PW, D'Agostino RB, Sullivan L, Parise H, Kannel WB. Overweight and obesity as determinants of cardiovascular risk: the Framingham experience. Arch Intern Med. 2002;162(16):1867-72.

28. Hastie CE, Padmanabhan S, Slack R, Pell AC, Oldroyd $\mathrm{KG}$, Flapan AD, et al. Obesity paradox in a cohort of 4880 consecutive patients undergoing percutaneous coronary intervention. Eur Heart J. 2010;31(2):222-6.
29. Oreopoulos A, Padwal R, Norris CM, Mullen JC, Pretorius V, Kalantar-Zadeh K. Effect of obesity on short- and long-term mortality postcoronary revascularization: a meta-analysis. Obesity (Silver.Spring). 2008;16(2):442-50.

30. Costa JL, Goh BK. Peak espiratory flow rate in normal adult chinese in singapore. Singapore Med J. 1973;14(4):511-4.

Received: 01/30/2013

Recebido: 30/01/2013

Approved: 09/12/2013

Aprovado: 12/09/2013 